\title{
A RESEARCH-BASED STUDY OF FOREIGN STUDENTS' USE OF GRAMMATICAL CODES IN FIVE LEADING BRITISH LEARNERS' DICTIONARIES
}

\begin{abstract}
Grammatical codes are one of several ways of including grammar in learners' dictionaries. In our research we focussed on the usability and user-friendliness of learners' dictionaries as regards grammatical information. The results presented and discussed in this article are based on answers obtained by a questionnaire that tested the understanding of codes found in five leading British monolingual learners' dictionaries and the success of the explanations of the same codes provided in the front matter of each dictionary. The results are presented by dictionaries and by codes. The most important finding of this research is that the understanding of the code and thus its usefulness depends on the code itself rather than on the dictionary.
\end{abstract}

\section{Introduction}

Dictionaries, especially monolingual dictionaries designed to meet the needs of a foreign language learner, contain a large amount of information of various types. Early studies conducted into dictionary use (Barnhart 1962, Quirk 1973, Béjoint 1981, Tomaszczyk 1979) show that dictionaries are most often used for checking the meaning of unknown words. Apart from meaning, other types of information are also included and used by dictionary users but to a lesser extent than meaning. Undoubtedly, one of the important elements of monolingual learners' dictionaries is the inclusion of grammar (McCorduck 1993). Grammar has been included in learners' dictionaries since the very beginning (Cowie 1999), but the amount of grammar in dictionaries has increased noticeably in the course of time (Béjoint 2000: 29). Typically, all monolingual learners' dictionaries include the part of speech label, which represents grammatical information about words, where they can operate in the syntax of sentences, and what their combinatorial possibilities are. Other grammatical information refers to various grammatical properties of each individual word class, such as countability in nouns, verb patterns, attributive, postpositive, and predicative use of adjectives, as well as gradability in adjectives and adverbs (Herbst 1989, Jackson 2002, Landau 2001, Cowie 1999). Grammatical information is provided in the form of codes or abbreviated phrases as well as more indirectly, i.e. in definitions and examples of use. The question of what should be taken into consideration when including grammatical information has been widely discussed (Jackson 1985, Lemmens and Wekker 1986, Sinclair 1987), but it is of the greatest importance to 
know what dictionary users understand and make use of when consulting their dictionaries in terms of grammar. The only way to find this out is to carry out research into different aspects of dictionary use, including grammar. Surveys should enquire into students' awareness of the existence of grammatical information in learners' dictionaries. Several aspects have been tested so far, such as syntax, complementation codes and labels (Nuccorini 1992), the obligatory use of the article, verb patterns, and countability (Tono 2001), and verb patterns, especially verb complementation (Bogaards, van der Kloot 2001). The results show that grammar is rarely looked up by the test subjects; they do not use all the available information, and they tend to choose the first definition in the entry rather than read the whole entry (this applies especially to long entries), even though useful grammatical information may be included later in the entry. Several comparisons of codes used in different learners' dictionaries have also been made, investigating the system of grammatical codes (Aarts 1991, Dalgish 1995, Strevens 1987), the thoroughness and consistency in the use of grammatical codes (Heath 1982), and the transparency of codes (Aarts 1991, Herbst 1989, Strevens 1987). The most commonly expressed criticism refers to the fact that codes are not sufficiently transparent, therefore not sufficiently user-friendly. The main proposal is that a coding system should be self-explanatory and reasonably easy to use.

In order to test the transparency and usability of grammatical codes included in the latest editions of five leading British monolingual dictionaries, we carried out a survey, the results of which are presented and discussed in this article. Research was undertaken to prove our hypothesis that dictionary users do not regularly consult the front matter in order to check a code or an abbreviated phrase they do not understand. We, therefore, wanted to find out to what extent the codes or abbreviated phrases are understood without being explained (are they so clear that the explanation is redundant, or are they so difficult that they cannot be understood without an explanation?).

\section{Methodology}

\subsection{Test Subjects}

Research was carried out among second- and third-year students of the Faculty of Economics (hereafter referred to as FE) and fourth-year students of the Faculty of Arts (hereafter referred to as FA), Department of English, University of Ljubljana, Slovenia. Together the groups comprised 162 respondents. One hundred and fifty-seven respondents (i.e. $96.9 \%$ ) speak Slovene as their mother tongue, and 5 (i.e. $3.1 \%$ ) speak some other language as their mother tongue. The test subjects were asked to give details about the number of years they had been studying English. Most of the respondents (i.e. $69.1 \%$ ) had been studying English for $10-12$ years; $15.4 \%$ had been studying it for less than 10 years, and $15.4 \%$ for more than 12 years. Our test subjects were considered as belonging to a quite homogenous group: most of them attended schools in Slovenia; they had the same number of English lessons per year and covered the same syllabus. For these reasons we considered it unnecessary for them to undergo a placement test. However, we did enquire about the students' average grades in 
English in grammar school. The majority of students indicated that their average school grade in English was either A or B (37\% stated Grade A and $34.6 \%$ stated Grade B); $24.1 \%$ had a Grade of C and only $4.3 \%$ a Grade of D.

\subsection{Test Design}

The questionnaire consisted of two parts: a Dictionary User Profile Form and a Dictionary Research Test. The Dictionary User Profile Form was completed by all test subjects and was aimed at obtaining information about the dictionary users, i.e. their mother tongue, how long they have been studying English, and their grades in grammar school (cf. 2.1 Test Subjects).

The Dictionary Research Test concentrated on the respondents' abilities to decipher the grammatical codes included in five leading British monolingual learners' dictionaries: COBUILD4, OALD6, CALD2, LDOCE4, and MED1. It consisted of two tasks. In both tasks, the respondents were subdivided into five groups depending on the dictionary tested. Thirty-two students were given ten grammatical codes or abbreviated phrases from MED1, 32 from OALD6, 31 from LDOCE4, 36 from COBUILD4, and 31 from CALD2. In Task 1, the students were supposed to explain the code or the abbreviated phrase taken from the above-mentioned dictionaries. It was aimed at testing students' understanding of the codes. The students did not have to use the appropriate terminology; they could also explain their understanding in their mother tongue or provide an example. Task 2 , on the other hand, included the same codes with the explanations taken from the front matter of each dictionary. It was aimed at testing the understanding of the explanations of these codes or abbreviated phrases.

\subsection{Procedure of data collection}

For the purpose of this study, data were collected by means of a questionnaire. Test subjects were given the questionnaire, and the researchers explained what they had to do. The respondents were supposed to complete the questionnaire in 45 minutes. The respondents' answers were appropriately coded and prepared for a statistical analysis using the Microsoft Excel program. Standard statistical methods were used for the data processing, which was carried out by the SPSS for Windows, version 11.

\section{Results of the Dictionary Research Test}

In Task 1, the range of correct answers in all the dictionaries tested is quite broad (from $12.5 \%$ to $87.5 \%$ in OALD6, from $3.2 \%$ to $90.3 \%$ in LDOCE4, from $11.1 \%$ to $88.9 \%$ in COBUILD4, and from $0.0 \%$ to $90.3 \%$ in CALD2). The only dictionary where the percentage of correct answers is somehow more balanced is MED1, where the difference between the best and the worst result is also quite large but still smaller than in other dictionaries (between $46.9 \%$ and $96.9 \%$ ).

In Task 2, where the understanding of the explanations of the codes or abbreviated phrases was tested, COBUILD4 has to be mentioned as the dictionary where the difference between the explanation that was understood by the highest percentage of 
the respondents $(97.2 \%)$ and that which was understood by the lowest percentage of the students $(22.2 \%)$ is most noticeable. In MED1, the difference between the explanation that was understood by the highest percentage of the students $(100.0 \%)$ and that which was understood by the lowest percentage of the respondents $(62.5 \%)$ is the smallest, whereas the results range from $58.1 \%$ to $100.0 \%$ in CALD2, from $43.8 \%$ to $100.0 \%$ in OALD6, and from $38.7 \%$ to $100.0 \%$ in LDOCE4.

Let us consider the individual codes and abbreviated phrases included in all the above-mentioned dictionaries.

The codes or abbreviated phrases in MED1 do not seem to pose great problems to dictionary users. Among the codes that were the most problematic we have to mention code 8 'in imperative', code 1 'linking verb', and code 7 'usually progressive'. Code 6 ('usually passive') with $96.9 \%$, code 4 ('never before noun') with $87.5 \%$, and code 10 ('in negatives or questions') with $87.5 \%$ are the most successful ones.

A comparison of results concerning the explanation of the codes found in the front matter shows that only the explanation for code 6 ('usually used in the passive') was understood by all the test subjects. The explanations for code 3 ('adjectives that can only be used before a noun'), code 4 ('adjectives that can never be used before a noun'), code 10 ('usually used in negative sentences or questions'), and code 9 ('usually used in the infinitive') also proved successful, since they were all understood by more than $90 \%$ of the respondents. The respondents found the explanations for code 7 ('usually used in the progressive') and code 8 ('usually used in the imperative') the most difficult ones, since they were understood by $62.5 \%$ and $65.6 \%$ of the test subjects respectively. Here a parallel can be drawn with the results in Task 1, where the same codes were understood by a relatively small number of respondents. For more detailed results concerning the success in deciphering the codes and understanding their explanations in MED1, see Table 1.

Table 1: Success in deciphering and understanding the grammatical codes in MED1 (in \%)

\begin{tabular}{|l|l|l|l|l|l|l|l|l|l|l|}
\hline $\begin{array}{l}\text { Stud. } \\
\text { resp. }\end{array}$ & $\begin{array}{l}\text { Code } \\
1\end{array}$ & $\begin{array}{l}\text { Code } \\
2\end{array}$ & $\begin{array}{l}\text { Code } \\
3\end{array}$ & $\begin{array}{l}\text { Code } \\
4\end{array}$ & $\begin{array}{l}\text { Code } \\
5\end{array}$ & $\begin{array}{l}\text { Code } \\
6\end{array}$ & $\begin{array}{l}\text { Code } \\
7\end{array}$ & $\begin{array}{l}\text { Code } \\
8\end{array}$ & $\begin{array}{l}\text { Code } \\
9\end{array}$ & $\begin{array}{l}\text { Code } \\
10\end{array}$ \\
\hline Cor. & 50.0 & 78.1 & 84.4 & 87.5 & 68.8 & 96.9 & 53.1 & 46.9 & 75.0 & 87.5 \\
\hline U & 78.1 & 87.5 & 96.9 & 93.8 & 87.5 & 100.0 & 62.5 & 65.6 & 90.6 & 93.8 \\
\hline
\end{tabular}

Stud. resp. - students' responses

Cor. - the respondent managed to explain the code correctly

$\mathrm{U}$ - the respondent understood the explanation of the code

Among the grammatical codes taken from OALD6, code 10 ('VN speech') proved to be the most difficult one, since it was correctly explained by only $12.5 \%$ of the respondents. The most difficult part of this code is most certainly the second element ('speech'), since $71.9 \%$ of the respondents correctly explained code 3 ('VN'), which corresponded to the first element in code 10 . Less than $50 \%$ of the test subjects were able to explain the meaning of code 4 ('VN + adv./prep.') and code 9 ('VN -ing'). 
Code 2 ('pt') and code 5 ('V-ADJ') were correctly explained by $81.3 \%$ and $87.5 \%$ of the respondents respectively, a result which means that they are among the most successful codes in OALD6.

As regards the explanations of the codes, code 2 ('past tense') was the most successfully explained, which is understandable, given that all language learners are familiar with the term 'past tense'. Apart from code 2, code 3 ('verb + noun phrase'), code 1 ('past participle'), code 5 ('verb + adjective'), and code 7 ('verb + that clause') are also explained in such a way that the majority of respondents are able to understand them. The most problematic code seems to be code 10 ('verb + noun phrase + direct speech'), whose explanation was understood by only $43.8 \%$ of respondents. The same code also yielded the worst result in Task 1 , and even the explanation provided in the front matter does not help as much as it should. Detailed results of student success in diciphering the codes and understanding of the explanations of the codes are presented in Table 2.

Table 2: Success in deciphering and understanding the grammatical codes in OALD6 (in \%)

\begin{tabular}{||l|l|l|l|l|l|l|l|l|l|l||}
\hline $\begin{array}{l}\text { Stud. } \\
\text { resp. }\end{array}$ & $\begin{array}{l}\text { Code } \\
1\end{array}$ & $\begin{array}{l}\text { Code } \\
2\end{array}$ & $\begin{array}{l}\text { Code } \\
3\end{array}$ & $\begin{array}{l}\text { Code } \\
4\end{array}$ & $\begin{array}{l}\text { Code } \\
5\end{array}$ & $\begin{array}{l}\text { Code } \\
6\end{array}$ & $\begin{array}{l}\text { Code } \\
7\end{array}$ & $\begin{array}{l}\text { Code } \\
8\end{array}$ & $\begin{array}{l}\text { Code } \\
9\end{array}$ & $\begin{array}{l}\text { Code } \\
10\end{array}$ \\
\hline Cor. & 62.5 & 81.3 & 71.9 & 40.6 & 87.5 & 71.9 & 68.8 & 53.1 & 40.6 & 12.5 \\
\hline U & 90.6 & 100.0 & 93.8 & 68.8 & 90.6 & 84.4 & 90.6 & 78.1 & 78.1 & 43.8 \\
\hline
\end{tabular}

In comparison to MED1 and OALD6, the codes included in LDOCE4 are less transparent. Only code 5 ('only before noun') was understood by more than $90 \%$ of the respondents. As many as five codes were understood by less than $50 \%$ of the students, which is far from being satisfactory. Code 9 ('+ adj/adv') was deciphered by $3.2 \%$ of the respondents only. The explanation of this code ('shows that an adverb of degree is used before adjectives and adverbs') seems to be more successful, since $51.6 \%$ of the respondents were able to understand it. Apart from code 9, code 10 ('also + plural verb BrE') was also a problematic one, since less than $20 \%$ of the test subjects managed to explain it correctly. Again, the explanation ('shows that a group noun can take a plural verb in British English') was understood by $77.4 \%$ of the respondents, which is quite a good result in comparison to the ability of the test subjects to explain the code. Another code that gave students problems is code 8 ('sentence adverb'), which was appropriately explained by only $23.3 \%$ of the respondents. The explanation of this code ('shows that an adverb modifies a whole sentence') provided in the front matter is not of great help to dictionary users, either, since it was understood by only $38.7 \%$ of the respondents. Apart from code 5 (already mentioned) the most successful codes include code 7 ('only after noun'), and code 6 ('not before noun'), as they both were successfully deciphered by more than $80 \%$ of the respondents. Similarly, the explanations of these three codes were clear enough to be understood by the majority of respondents (the explanations for codes 5 and 6 were understood by all the respondents, and the explanation for code 7 by $96.8 \%$ ). The greatest difference 
between correct answers that show students' ability to decipher the code and those that show that respondents understood the explanation of the code can be found with code 2. Only $41.9 \%$ of students understood the code, as opposed to $100.0 \%$ of students who understood the explanation of the code. Further details concerning students' ability to decipher the code and understand its explanation are presented in Table 3 .

Table 3: Success in deciphering and understanding the grammatical codes in LDOCE4 (in \%)

\begin{tabular}{|l|l|l|l|l|l|l|l|l|l|l|}
\hline $\begin{array}{l}\text { Stud. } \\
\text { resp. }\end{array}$ & $\begin{array}{l}\text { Code } \\
1\end{array}$ & $\begin{array}{l}\text { Code } \\
2\end{array}$ & $\begin{array}{l}\text { Code } \\
3\end{array}$ & $\begin{array}{l}\text { Code } \\
4\end{array}$ & $\begin{array}{l}\text { Code } \\
5\end{array}$ & $\begin{array}{l}\text { Code } \\
6\end{array}$ & $\begin{array}{l}\text { Code } \\
7\end{array}$ & $\begin{array}{l}\text { Code } \\
8\end{array}$ & $\begin{array}{l}\text { Code } \\
9\end{array}$ & $\begin{array}{l}\text { Code } \\
10\end{array}$ \\
\hline Cor. & 41.9 & 41.9 & 54.8 & 54.8 & 90.3 & 80.6 & 87.1 & 23.3 & 3.2 & 19.4 \\
\hline U & 67.7 & 100.0 & 93.5 & 93.5 & 100.0 & 100.0 & 96.8 & 38.7 & 51.6 & 77.4 \\
\hline
\end{tabular}

Generally speaking, codes in COBUILD4 give cause for concern. Only one code (code 7 - 'V-PASSIVE') was understood by $88.9 \%$ of the students. The results show that code 4 ('N-VAR') with $11.1 \%$, code 1 ('PREP-PHRASE') with $13.9 \%$, and code 3 ('N-COUNT-COLL') with $27.8 \%$ were the most difficult ones. The results showing how well the students understood the explanation of the codes indicate that the explanations for code 7 ('passive verb'), code 2 ('comparative form'), and code 9 ('imperative') were understood by the majority of respondents, whereas the explanation for code 4 ('variable noun') was understood by only $22.2 \%$ of respondents. For more detailed results, see Table 4.

Table 4: Success in deciphering and understanding the grammatical codes in COBUILD4 (in \%)

\begin{tabular}{|l|l|l|l|l|l|l|l|l|l|l|}
\hline $\begin{array}{l}\text { Stud. } \\
\text { resp. }\end{array}$ & $\begin{array}{l}\text { Code } \\
1\end{array}$ & $\begin{array}{l}\text { Code } \\
2\end{array}$ & $\begin{array}{l}\text { Code } \\
3\end{array}$ & $\begin{array}{l}\text { Code } \\
4\end{array}$ & $\begin{array}{l}\text { Code } \\
5\end{array}$ & $\begin{array}{l}\text { Code } \\
6\end{array}$ & $\begin{array}{l}\text { Code } \\
7\end{array}$ & $\begin{array}{l}\text { Code } \\
8\end{array}$ & $\begin{array}{l}\text { Code } \\
9\end{array}$ & $\begin{array}{l}\text { Code } \\
10\end{array}$ \\
\hline Cor. & 13.9 & 61.1 & 27.8 & 11.1 & 33.3 & 58.3 & 88.9 & 41.7 & 66.7 & 58.3 \\
\hline $\mathrm{U}$ & 66.7 & 83.3 & 50.0 & 22.2 & 52.8 & 69.4 & 97.2 & 77.8 & 80.6 & 63.9 \\
\hline
\end{tabular}

The questionnaires tested the success of 50 codes - i.e. 10 codes taken from each dictionary - but the only code that was not understood by a single respondent was code 5 ('M') from CALD2. Even the explanation itself (i.e. 'phrasal verb with a particle that can come before or after the object') is not really revealing, since only $58.1 \%$ of the students managed to understand it. This result is not a complete failure, but if we compare it with other results for explanations of codes in this dictionary, it is the worst one. Besides code 5, we have to mention code 4 (' $L$ ') and code 8 (' $R$ '), which were appropriately explained by less than $10 \%$ of the respondents. Again, a single letter is not self-explanatory; therefore students did not manage to decipher ' $L$ ' as referring to linking verbs and ' $R$ ' as referring to reflexive verbs. Also worth mentioning is code 9 (' $S$ '), which was correctly explained by $35.5 \%$ of the students. All the users understood this code after having read the explanation. A comparison of the results 
showing how well the students understood the explanations of the codes reveals a completely different picture. As many as three explanations (code 3 - 'adjective that is placed only before a noun'; code 9 - 'singular'; code 10 - 'verb usually used in the passive') were understood by all respondents. Effective explanations also include those for code 6 ('verb with an object followed by a noun or an adjective') and code 7 ('verb with an object followed by the -ing form of another verb'), which were understood by more than $90 \%$ of the test subjects. More detailed results are presented in Table 5.

Table 5: Success in deciphering and understanding the grammatical codes in CALD2 (in \%)

\begin{tabular}{||l|l|l|l|l|l|l|l|l|l|l||}
\hline $\begin{array}{l}\text { Stud. } \\
\text { resp. }\end{array}$ & $\begin{array}{l}\text { Code } \\
1\end{array}$ & $\begin{array}{l}\text { Code } \\
2\end{array}$ & $\begin{array}{l}\text { Code } \\
3\end{array}$ & $\begin{array}{l}\text { Code } \\
4\end{array}$ & $\begin{array}{l}\text { Code } \\
5\end{array}$ & $\begin{array}{l}\text { Code } \\
6\end{array}$ & $\begin{array}{l}\text { Code } \\
7\end{array}$ & $\begin{array}{l}\text { Code } \\
8\end{array}$ & $\begin{array}{l}\text { Code } \\
9\end{array}$ & $\begin{array}{l}\text { Code } \\
10\end{array}$ \\
\hline Cor. & 25.8 & 67.7 & 77.4 & 6.5 & 0.0 & 58.1 & 58.1 & 9.7 & 35.5 & 90.3 \\
\hline $\mathrm{U}$ & 83.9 & 71.0 & 100.0 & 64.5 & 58.1 & 93.5 & 93.5 & 61.3 & 100.0 & 100.0 \\
\hline
\end{tabular}

\section{Discussion}

These results clearly show that the test subjects find some codes or abbreviated phrases fairly transparent, whereas others prove to be quite difficult. It is surprising, for example, that respondents had problems with the abbreviated phrase in imperative', since they come across the term 'imperative' in the course of learning English, but it is understandable that they did not know the meaning of the abbreviated phrase 'linking verb', since this is not used when teaching English grammar at school. The term 'linking verb' is known only to the students of English who get acquainted with it in their grammar courses at the university, when discussing the classification of the verbs. The general dictionary user, on the other hand, cannot possibly be familiar with the meaning of this term.

The term 'progressive' also poses problems because it is not used in textbooks, the result being that students are not familiar with it. At school, the term 'continuous' is used, and it can be assumed that this term would be much better understood. It has to be stressed that all the textbooks that are officially approved for use in primary and grammar schools in Slovenia are published by the same publishing houses as the monolingual learners' dictionaries (e.g. Cambridge English for Schools - Cambridge University Press; Project - Oxford University Press; New Headway English Course Oxford University Press; Matrix - Oxford University Press; Natural English - Oxford University Press). The same terminology can justifiably be expected in textbooks as well as dictionaries intended for the same target audience. It is true that in primary school and at least at the beginning of grammar school the level of English is not sufficient to enable the use of the dictionaries tested, which are intended for advanced learners. Advanced learners, however, have experienced many years of learning English, and the basic learning aid they have used has been the school textbooks. One would, however, expect a better result with ' $v$-cont' (in COBUILD4), where the term 
'continuous' is used, as opposed to the term 'progressive', which is used in other learners' dictionaries. It is possible that our respondents did not manage to understand the abbreviated form of the term (cont for continuous), but even the results showing how many students understood the explanation provided for this code are not as high as one would expect. The students seem to have been puzzled by the entire expression 'continuous verb', which is used in the front matter of this dictionary, as they are more familiar with the term 'continuous tense' rather than with the term 'continuous verb'.

Another complicated abbreviated phrase is 'sentence adverb', since a general dictionary user does not understand the concept underlying this term. This is a term language learners do not come across when learning English; they become acquainted with it as late as their grammar classes at the university (if they study English). The terms 'variable noun', 'prepositional phrase', 'collective countable noun', and 'reciprocal verb' are also much too complicated for an average dictionary user. The results for these abbreviated phrases are unsatisfactory and the reason for such poor results is most certainly the terminology used.

What about one-letter codes? The code ' $S$ ' used in CALD2 proved to be quite difficult, which is surprising if we know that this code refers to 'singular'. In this particular example, the difficulty lies in the code itself not in the terminology used. In other learners' dictionaries the code 'sing.' is used (OALD6 and COBUILD4), or the word 'singular' is written in full (MED1 and LDOCE4). We also cannot ignore the code ' $\mathrm{M}$ ' (used in CALD2), which is the only code (out of all 50 codes tested) that was not understood by a single respondent. What is it that makes this code so complicated? As we learn from the explanation of this code, it refers to a 'phrasal verb with a particle that can come before or after the object'. The code 'M' suggests that the object can occupy the medial position between the verb and the particle, but the code itself is not self-explanatory. How can a dictionary user know that ' $M$ ' stands for medial position?

In codes consisting of several elements, such as 'VN speech', 'VN + adv./prep.', 'VN -ing', we can presuppose that it was the second element that the respondents were unable to understand, taking into account that the code 'VN' was not problematic. Probably, the reason cannot be attributed to the fact that the students do not know what 'speech', 'adv./prep.' or '-ing' mean; it is rather that they do not know what the entire code refers to. The same holds true of the codes ' $+\mathrm{adj} / \mathrm{adv}$ ', 'always $+\mathrm{adv} / \mathrm{prep}$ ' found in LDOCE4, since they consist of elements that average dictionary users would know, but probably users are unable to link the elements and understand what the entire code means. Consequently, the verbalization of these two codes ('shows that an adverb of degree is used before adjectives and adverbs' and 'shows that a verb must be followed by an adverb or a preposition') is perfectly clear, and is thus understood by all respondents. However, the explanation does not always prove successful, which is confirmed by the explanation of the code 'VN speech', meaning 'verb + noun phrase + direct speech'. The test subjects understood all parts of the explanation even the last part, i.e. 'direct speech', since they get acquainted with this term in the course of learning English, but in all likelihood, they were not able to make a connection between all three elements of the explanation. 
With a high degree of certainty it can be claimed that understanding of the code or abbreviated phrase and thus its usefulness depends on the code or abbreviated phrase itself rather than on the dictionary used. The compilers of the dictionaries provide as much grammatical information as possible, much of which is included in the form of grammatical codes or abbreviated phrases. As is shown in our research, the transparency and simplicity of the codes or abbreviated phrases are of the utmost importance if we want users to understand them and to make use of them. These results also confirm the findings of Aarts (1991), Herbst (1989), and Strevens (1987).

\section{Conclusion}

There is no doubt that dictionary reference skills involve highly complicated cognitive skills. Dictionary skills are problem-solving skills: users are trying to solve a particular linguistic conflict by consulting a dictionary. However, it should be emphasized that dictionary use is not as simple as one would imagine. A dictionary abounds with information of various types, and very often a dictionary user is not even aware of the wealth of information he/she can find when consulting a dictionary. We strongly believe that students should be made aware of the whole range of information included in monolingual learners' dictionaries, and the inclusion of codes and abbreviated phrases is no exception. The front matter of each dictionary where the types of information included in this particular dictionary are explained can be of great help. Unfortunately, many dictionary users never read it, the result being that they cannot be regarded as proficient dictionary users. The educational system can play an important role, since the teaching of dictionary skills could be integrated into the foreign language syllabus. An important tool in the training of dictionary users is the use of separate companion booklets that are meant to train users and offer them practice in using the special features, including grammatical codes. Systematic dictionary training is absolutely necessary to enable learners to become efficient dictionary users.

\section{References:}

\section{Dictionaries}

Rundell, M. (ed.) 2002. Macmillan English Dictionary for Advanced Learners. (First edition.) Oxford: Macmillan Publishers. (MED1)

SinClaIR, J., Sinclair Knight, L., and Clari, M. (eds.) 2003. Collins Cobuild Advanced Learner's English Dictionary. (Fourth edition.) Glasgow: HarperCollins Publishers. (COBUILD4)

Summers, D. (ed.) 2003. Longman Dictionary of Contemporary English. (Fourth edition.) Harlow, Essex: Pearson Education Limited. (LDOCE4)

WeHMEIER, S. (ed.) 2000. Oxford Advanced Learner's Dictionary. (Sixth edition.) Oxford: Oxford University Press. (OALD6)

Woodford, K. and Jackson, G. (eds.) 2003. Cambridge Advanced Learner's Dictionary. (Second edition.) Cambridge: Cambridge University Press. (CALD2)

\section{Other literature}

AARTS, F. 1991. "Lexicography and Syntax: The State of the Art in Learners' Dictionaries of English" in J. E. Alatis (ed.), Linguistics and Language Pedagogy: The State of the Art. Georgetown University Roundtable on Languages and Linguistics, 1991. Washington, D.C.: Georgetown University Press, 567-582.

Barnhart, C. 1962. "Problems in Editing Commercial Monolingual Dictionaries" in F. Householder and S. 
Saporta (eds.), Problems in Lexicography. International Journal of American Linguistics 28 (2) (April), Bloomington, Indiana: Indiana University Research Center in Anthropology, Folklore, and Linguistics, 161-181.

BÉJoINT, H. 1981. “The Foreign Student's Use of Monolingual English Dictionaries: A Study of Language Needs and Reference Skills.” Applied Linguistics 2 (3), 207-222.

BÉJoINT, H. 2000. Modern Lexicography: An Introduction. Oxford: Oxford University Press.

BOGAARDS, P. and van der Kloot, W. 2001. "The Use of Grammatical Information in Learners' Dictionaries." International Journal of Lexicography 14: 97-121.

CowIE, A. 1999. English Dictionaries for Foreign Learners. A History. Oxford: Oxford University Press.

DALGISH, G. 1995. “Learners' Dictionaries: Keeping the Learner in Mind?” in B. B. Kachru and H. Kahane (eds.), Cultures, Ideologies, and the Dictionary: Studies in Honor of Ladislav Zgusta. (Lexicographica Series Maior 64.) Tübingen: Max Niemeyer Verlag, 329-338.

HEATH, D. 1982. "The Treatment of Grammar and Syntax in Monolingual English Dictionaries for Advanced Learners." Linguistik und Didaktik 49/50: 95-107.

Herbst, T. 1989. "Grammar in Dictionaries" in M. L. Tickoo (ed.), Learners' Dictionaries: State of the Art. (Anthology Series 23) Singapore: SEAMEO Regional Language Centre: 94-111.

JACKSON, H. 1985. "Grammar in the Dictionary" in R. Ilson (ed.), Dictionaries, Lexicography and Language Learning. Oxford: Pergamon Press, 53-59.

JACKSON, H. 2002. Lexicography: An Introduction. London, New York: Routledge.

Landau, S. I. 2001. Dictionaries: The Art and Craft of Lexicography. Cambridge: Cambridge University Press.

LEMmENs, M. and Wekker, H. 1986. Grammar in English Learners' Dictionaries. (Lexicographica Series Maior 16.) Tübingen: Max Niemeyer Verlag.

MCCoRduCK, E. S. 1993. Grammatical Information in ESL Dictionaries. (Lexicographica Series Maior 48.) Tübingen: Max Niemeyer Verlag.

NucCorinI, S. 1992. "Monitoring Dictionary Use" in W. H. Tommola, K. Varantola, T. Salmi-Tolonen, and J. Schopp (eds.), Euralex '92 Proceedings I-II (Part I). Studia Translatologica, Ser. A, Vol. 2. Tampere, Finland: University of Tampere, 89-102.

QUIRK, R. 1973. "The Social Impact of Dictionaries in the U.K." in R. I. McDavid and A. R. Duckert (eds.), Lexicography in English. New York: Annals of the New York Academy of Sciences, 76-88.

SinClaiR, J. M. 1987. "Grammar in the dictionary" in J. M. Sinclair (ed.), Looking up: An Account of the COBUILD Project in Lexical Computing and the Development of the Collins COBUILD English Language Dictionary. London, Glasgow: Collins, 104-115.

StREVEnS, P. 1987. “The effectiveness of learners' dictionaries” in R. Burchfield (ed.), Studies in Lexicography. Oxford: Oxford University Press, 76-93.

TOMASZCZYK, J. 1979. "Dictionaries: Users and uses." Glottodidactica 12: 103-119.

ToNo, Y. 2001. Research on Dictionary Use in the Context of Foreign Language Learning. (Lexicographica Series Maior 106.) Tübingen: Max Niemeyer Verlag.

\section{Povzetek \\ RAZISKAVA O UPORABI SLOVNIČNIH KOD V PETIH VODILNIH BRITANSKIH ENOJEZIČNIH SLOVARJIH ZA TUJCE NA VZORCU TUJIH GOVORCEV}

Slovnične kode so eden od načinov vključevanja slovnice v enojezične slovarje za tujce. V raziskavi smo preučevali, v kakšni meri so ti slovarji uporabni in prijazni do uporabnika pri vključevanju slovničnih podatkov. Rezultati, predstavljeni v tem članku, temeljijo na odgovorih, ki smo jih dobili s pomočjo vprašalnika, s katerim smo testirali razumevanje kod, ki jih najdemo v petih vodilnih britanskih enojezičnih slovarjih za tujce. Poleg tega smo testirali razumljivost razlag istih kod, ki jih najdemo v uvodnem delu vsakega slovarja. Rezultati so predstavljeni po slovarjih in po kodah. Najpomembnejša ugotovitev te raziskave je, da sta razumevanje kode in posledično njena uporabnost odvisna od kode same in ne od slovarja. 


\section{Appendix I}

The Dictionary User Profile Form was produced in Slovene, so that respondents could complete the form in their native language. The questionnaire here is a translation of the original form.

\section{DICTIONARY USER PROFILE FORM}

The aim of this questionnaire is to discover how dictionaries can be improved. You can help us by filling in this questionnaire. The questions are about monolingual (i.e. English-English) dictionaries.

1. What is your native language?

2. How many years have you been learning English for?

3. What was your average grade in English in grammar school?

\section{Appendix II}

The Dictionary Research Test was produced in Slovene to ensure that participants in the project would read the questions in their own language. The questionnaire here is a translation of the Slovene original.

\section{DICTIONARY RESEARCH TEST}

Task 1: The following grammatical codes can be found in Oxford Advanced Learner's Dictionary $\left(6^{\text {th }}\right.$ edition). Please write down what each code means (you can explain it or provide an example).
1. $\mathrm{pp}$
2. $\mathrm{pt}$
3. $\mathrm{VN}$
4. $\mathrm{VN}+$ adv./prep.
5. V-ADJ
6. VN-ADJ
7. $\mathrm{V}($ that $)$
8. V wh-
9. $\mathrm{VN}$-ing
10. VN speech

Task 2: The codes from the previous task are accompanied by the explanations that can be found in the introductory part of the dictionary. Please indicate whether the explanation is clear enough for you to make use of it when using English actively. 
1. $\mathrm{pp}$

a. understand

2. $\mathrm{pt}$

a. understand

3. $\mathrm{VN}$

a. understand

4. $\mathrm{VN}+\mathrm{adv} . /$ prep.

a. understand

5. V-ADJ

a. understand

6. VN-ADJ

a. understand

7. V(that)

a. understand

8. V wh-

a. understand

9. $\mathrm{VN}$-ing

a. understand

10. VN speech

a. understand past participle

b. don't understand

past tense

b. don't understand

verb + noun phrase

b. don't understand

verb + noun phrase + adverb or prepositional

phrase

b. don't understand

verb + adjective

b. don't understand

verb + noun phrase + adjective

b. don't understand

verb + that clause

b. don't understand

verb + wh-clause

b. don't understand

verb + noun phrase + -ing phrase

b. don't understand

verb + noun phrase + direct speech

b. don't understand

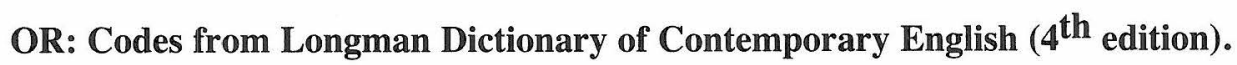

1. linking verb

2. always + adv/prep

3. not in progressive

4. no comparative

5. only before noun

6. not before noun

7. only after noun

8. sentence adverb

9. $+\mathrm{adj} / \mathrm{adv}$

10. also + plural verb $B r E$

\section{Codes from LDOCE4 with explanations}

1. linking verb

a. understand

2. always $+\mathrm{adv} / \mathrm{prep}$ a verb that is followed by a noun or adjective complement that describes the subjects of the verb b. don't understand shows that a verb must be followed by an adverb or a preposition 

a. understand
3. not in progressive
a. understand
4. no comparative

a. understand

5. only before noun

a. understand

6. not before noun

a. understand

7. only after noun

a. understand

8. sentence adverb

a. understand

9. $+\mathrm{adj} / \mathrm{adv}$

a. understand

10. also + plural verb $B r E$

a. understand b. don't understand

shows that a verb is not used in the progressive form, that is, the -ing form after 'be'

b. don't understand

shows that an adjective is not used in the comparative or superlative form, that is, not with -er and -est, or 'more' and 'most'

b. don't understand

shows that an adjective can be used only before a noun

b. don't understand

shows that an adjective cannot be used before a noun

b. don't understand

shows that an adjective is used only immediately after a noun

b. don't understand

shows that an adverb modifies a whole sentence

b. don't understand

shows that an adverb of degree is used before adjectives and adverbs

b. don't understand

shows that a group noun can take a plural verb in British English

b. don't understand

\section{OR: Codes from Macmillan English Dictionary (1 ${ }^{\text {st }}$ edition).}

1. linking verb

2. auxiliary verb

3. only before noun

4. never before noun

5. + (that)

6. usually passive

7. usually progressive

8. in imperative

9. in infinitive

10. in negatives or questions

\section{Codes from MED1 with explanations}

1. linking verb

verbs that are followed by a noun or adjective complement describing the subject 

a. understand
2. auxiliary verb

a. understand

3. only before noun

a. understand

4. never before noun

a. understand

5. + (that)

a. understand

6. usually passive

a. understand

7. usually progressive

a. understand

8. in imperative

a. understand

9. in infinitive

a. understand

10. in negatives or questions

a. understand b. don't understand

verbs 'be', 'have', and 'do' when they are used with other verbs to form questions, show their tense, etc

b. don't understand

adjectives that can only be used before a noun

b. don't understand

adjectives that can never be used before a noun

b. don't understand

can be followed by a clause beginning with 'that' but you can miss out the 'that'

b. don't understand

usually used in the passive

b. don't understand

usually used in the progressive

b. don't understand

usually used in the imperative

b. don't understand

usually used in the infinitive

b. don't understand

usually used in negative sentences or questions

b. don't understand

OR: Codes from Collins Cobuild English Dictionary for Advanced Learners (4 $4^{\text {th }}$ edition).

1. PREP-PHRASE

2. adj-compar

3. N-COUNT-COLL

4. N-VAR

5. V-RECIP

6. V-LINK

7. V-PASSIVE

8. v-cont

9. imper

10. pron-refl

\section{Codes from COBUILD4 with explanations}

1. PREP-PHRASE

a. understand

2. adj-compar

a. understand phrasal preposition

b. don't understand comparative form

b. don't understand 

3. N-COUNT-COLL
collective count noun
a. understand
b. don't understand
4. N-VAR
variable noun
a. understand
b. don't understand
5. V-RECIP
reciprocal verb
a. understand
b. don't understand
6. V-LINK
link verb
a. understand
b. don't understand
7. V-PASSIVE
passive verb
a. understand
b. don't understand
8. v-cont
continuous verb
a. understand
b. don't understand
9. imper
imperative
a. understand
b. don't understand
10. pron-refl reflexive pronoun
a. understand
b. don't understand

OR: Codes from Cambridge Advanced Learner's Dictionary ( $2^{\text {nd }}$ edition).
1. always $+\mathrm{adv} / \mathrm{prep}$
2. + question word
3 . before $n$
4. L
5. $\mathrm{M}$
6. + obj $+\mathrm{n} / \mathrm{adj}$
7. + obj $+v-i n g$
8. $\mathrm{R}$
9. $\mathrm{S}$

10. usually passive

\section{Codes from CALD2 with explanations}

1. always $+\mathrm{adv} / \mathrm{prep}$

a. understand

2. + question word

a. understand

3 . before $n$

a. understand

4. L

a. understand

5. $\mathrm{M}$ verb that must be followed by an adverb or preposition

b. don't understand verb with a question word b. don't understand adjective that is placed only before a noun b. don't understand linking verb (followed by an adjective or noun) b. don't understand phrasal verb with a particle that can come before or after the object 

a. understand
b. don't understand
6. + obj $+n / a d j$ verb with an object followed by a noun or an adjective
a. understand
b. don't understand
7. + obj + v-ing verb with an object followed by the -ing form of another verb
a. understand
b. don't understand
8. $\mathrm{R}$ reflexive
a. understand
b. don't understand
9. $\mathrm{S}$ singular
a. understand
b. don't understand
10. usually passive verb usually used in the passive
a. understand b. don't understand 